\title{
Mosquito Repellent Activity of Tridax procumbens Leaves- A Commercial Product
}

\author{
Sabarinath .K ${ }^{1}$ | Logeshwaran .V2 | Sandhiya.S | Ishwarya .R R $^{4}$ Kousalya.N5 | Arun.P ${ }^{6}$ \\ 1,2,3,4,5 Student, Department of Biotechnology, Dr. N. G. P. Arts and Science College, Coimbatore, India. \\ ${ }^{6}$ Associate Professor, Department of Biotechnology, Dr. N. G. P. Arts and Science College, Coimbatore, India.
}

\section{To Cite this Article}

Sabarinath .K, Logeshwaran .V, Sandhiya.S, Ishwarya .R, Kousalya.N and Arun.P, "Mosquito Repellent Activity of Tridax procumbens Leaves- A Commercial Product", International Journal for Modern Trends in Science and Technology, 6(12): $342-347,2020$.

\section{Article Info}

Received on 12-November-2020, Revised on 05-December-2020, Accepted on 11-December-2020, Published on 15-December-2020.

\section{ABSTRACT}

Tridax procumbeans is a weed plant native to tropical America and also seen in other tropical regions. Recent studies on the seed germination of Tridax procumbeans showed that they are $\mathrm{pH}$ resistance and they are able to grow in sea water. Although Tridax procumbeans is used as a medication plant in Ayurveda, the plant is famous for its wound healing and anticoagulation activity in modern days. As it is the asteraceae family, WHO claims that terpenoids and triterpenoids present in them have a strong insecticidal property. This study is carried to know the insecticidal property of Tridax procumbens leaves against mosquitos.

KEYWORDS: Tridax procumbeans, Insecticidal property, Mosquitos, Mosquito Repellent, Triterpenoids

\section{INTRODUCTION \\ Tridax procumbens Linn. (Tridax) family}

Composite regularly known as 'Ghamra' and in English prevalently called 'coat catches' a result of appearance of blossoms has been broadly utilized in Ayurvadic arrangement of medication for different afflictions and is administered for "Bhringraj" by a few of the specialists of Ayurveda which is well known medication for liver issue. (Bhagwatet al. 2008)

$\begin{array}{ll}\text { Kingdom } & \text { : Plantae } \\ \text { Sub Kingdom } & \text { : Tracheobionta } \\ \text { Division } & \text { : Magnoliophyta } \\ \text { Class } & \text { : Magnoliopsida } \\ \text { Sub Class } & \text { : Asteridae }\end{array}$

$\begin{array}{ll}\text { Order } & : \text { Asterales } \\ \text { Family } & \text { : Asteraceae } \\ \text { Genus } & : \text { Tridax } \\ \text { Species } & \text { : procumbens }\end{array}$

Coat catches are found along side of the road, squander grounds, embankments, railways, riverbanks, glades, and rises. Its broad circulation and significance as a weed are because of its spreading stems and copious seed creation. Tridax is seven days straying herb around $12-24 \mathrm{~cm}$ long with barely any leaves $6-8 \mathrm{~cm}$ long and exceptionally long thin single peduncles a foot or more long. Leaf is straightforward, inverse, exstipulate, praise, intense with two kinds of blossoms, for example, ray florets and disc florets. 


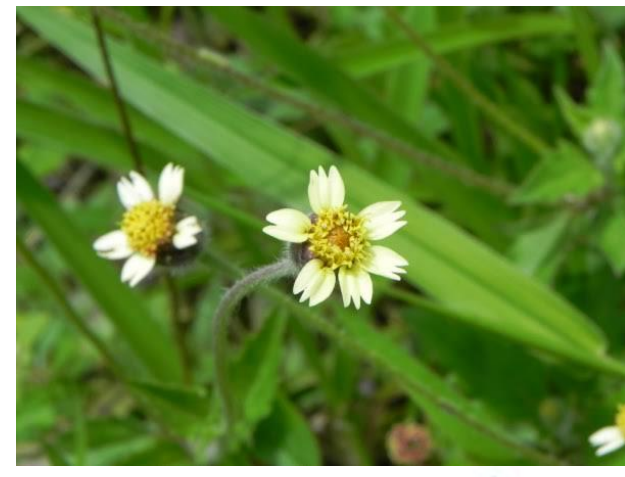

Figure 1.Tridax procumbens
Tridax procumbens ordinarily known as "Thatapoodu" in tamil is known for a few potential remedial exercises like antiviral, anti-infection efficacies, wound healing, insecticidal and anti-inflammatory action. (Everittet al. 2007)

Plants being a characteristic wellspring of different mixes are known to contain larviciding operators, which may act in blend or freely. A few phytochemicals go about as general toxicants both against the grown-up just as larval phases of mosquitoes, while others meddle with the development and improvement, multiplication, produce olfactory upgrades activities as an anti-agents or attractant. (Ghayalet al. 2010)

Natural items are best choice since it is less destructive to environment and non - targeted living beings. A few concentrates and compound from various plants families have been assessed for new and promising larvicides. (Ester et al. 2008)

Mosquitoes are the vectors for different deadful ailments of humankind. Of the considerable number of bugs that transmit ailments, mosquitoes speak to the most noteworthy threat. World Health Organization (WHO) has proclaimed mosquitoes as general wellbeing bug all through the world as they are liable for the transmission of different infection causing pathogens. (WHO et al. 1996)

\section{MATERIALS AND METHODS}

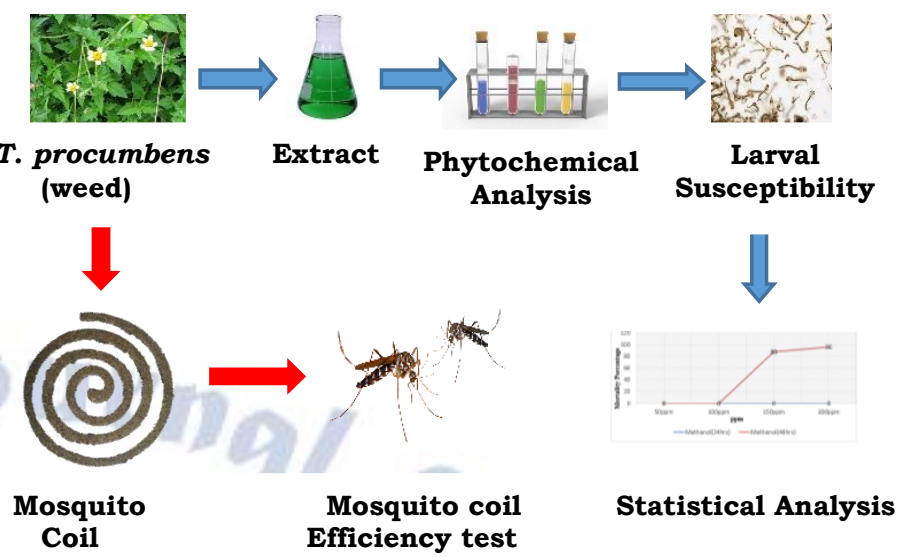

\section{COLLECTION OF PLANT MATERIAL}

The sample used in the present study was Tridax procumbens leaves collected from Dr. N. G. P. Arts and Science College, Coimbatore, Tamil Nadu, India. The plant was authenticated by Tamil Nadu Agriculture University, Coimbatore. The collected plant leaves were washed thoroughly in running tap water to remove the surface microflora and adherents, shade dried, finely powdered and stored in airtight container for future use.

\section{EXTRACTION OF PLANT LEAVES}

Extraction of plant leaves was carried out in a simplest way, thinking that it could be easy for the local communities to adopt this method. The extraction of powdered leaves sample was done by $10 \mathrm{~g}$ of leave powder was placed in $100 \mathrm{ml}$ of distilled water was added and mixed vigorously. The mixture was kept for 3 days with shaker at $100 \mathrm{rpm}$, mixture was filtered using a fine muslin cloth and the extraction was concentrated.

\section{Phytochemical analysis}

The phytochemical analysis screening was carried out for with aqueous extract of leaves sample using standard procedures. The analysis of the presence of several phytochemical was listed in Table 1. 


\section{LARVICIDAL BIOASSAY}

The mosquito larvae were Culex quinquefasciatus were collected from National Center for Disease Control, Mettupalayam. Larvicidal assay of the crude extract were conducted using the fourth instar larvae of Culex quinquefasciatus. A total of three trials were carried out against vector mosquitoes for larval susceptibility test. Stock solution (1000ppm) of the extract was prepared by dissolving $100 \mathrm{mg}$ of crude extract in $1 \mathrm{ml}$ acetone and volume raised to 100 $\mathrm{ml}$ with distilled water. From this different dilution of 50ppm, $100 \mathrm{ppm}, 150 \mathrm{ppm}, 200 \mathrm{ppm}$ and 250 ppm were prepared in $200 \mathrm{ml}$ deionized water and 25 fourth instar larvae were released in it and mortality was scored after $24 \mathrm{~h}$ and $48 \mathrm{~h}$ the results were noted. The beakers were kept in a temperature control room at $28^{\circ} \mathrm{C} \pm 2{ }^{\circ} \mathrm{C}$ and the larvae were exposed to $200 \mathrm{ml}$ water containing served as control. All the above experiment results were collected and mortality rate was corrected by Abbott's formula (1925).

Mortality $=\%$ alive control $-\%$ alive treated $* 100$

$$
\% \text { alive in control }
$$

\section{STATISTICAL ANALYSIS}

The average larval mortality data were subjected for calculating probit analysis in EXCEL for LC50 value. These calculation are based on the method of Finney (1952).

\section{MOSQUITO coIL MAKING}

Mosquito coils was prepared based on the industrial method of production slight alteration is done to minimize the use of industrial machineries. The ingredient used are

$>$ Fresh leaves (Grinded)

$>$ Pulverized dried leaves

$>$ Starch

$>$ Candle wax
These ingredient were mixed in same ratio and made into paste. Then the paste is coil mold. And the molded ingredient was dried under sunlight for 1 hour (depends on climatic condition).

\section{MOSQUITO COIL EFFICIENCY TEST}

> Mosquitoes are stimulated by some factors, they are

1. $\mathrm{CO}_{2}$ exhale,

2. Body odor,

3. Lactic acid,

4. Secretion,

5. Alcohol consumption.

The product was given to two houses (totally 8 peoples). They are suggested to use the product with 1 day interval.

\section{Subjects are recommended,}

Not to take shower at evening,

$>$ Not allowed for alcohol consumption.

$>$ Not use any room spray, and perfumes.

The coil ash are disposed in correct manner.

\section{Parameters to be checked:}

$>$ Repllent activity

$>$ Irritability

$>$ Odor

$>$ Smoke visibility

$>$ Burning time

$>$ Diameter

$>$ Flexibility

$>$ Color

\section{RESULT AND DISCUSSION}
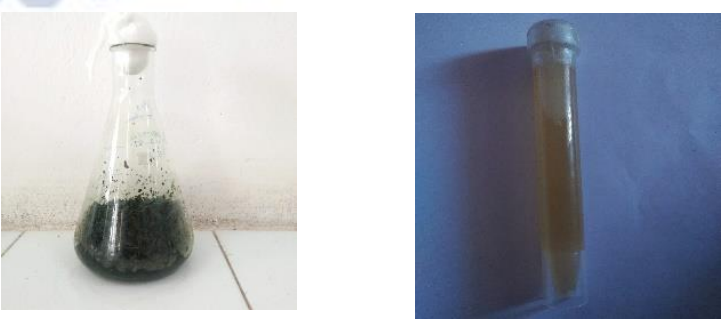

Figure 2.Extraction of plant leaves 


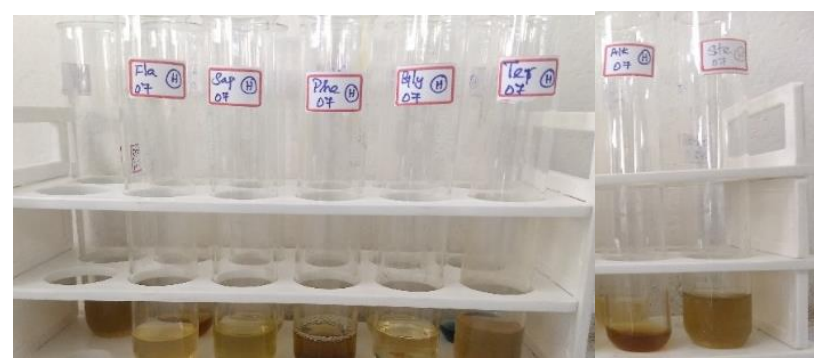

Figure 3. Phytochemical analysis

\begin{tabular}{|c|c|}
\hline Test for & Aqueous extract \\
\hline Alkaloids & - \\
\hline Phenols & - \\
\hline Flavonoids & + \\
\hline Tannins & + \\
\hline Saponins & - \\
\hline Terpenes & + \\
\hline Steroids & - \\
\hline
\end{tabular}

Table 1. Phytochemical analysis

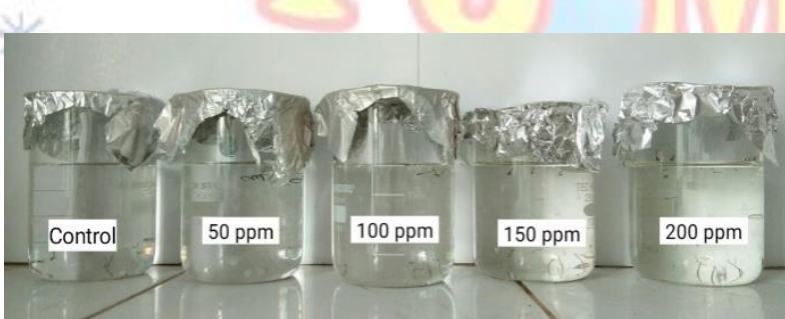

Figure 4. Larvicidal bioassay

\section{Statistical Analysis}

Larval mortality data were subjected for calculating probit analysis in EXCEL for LC50 value for both 24 hours and 48 hours calculation. Where $\mathrm{x}$ axis is ppm concentration and $\mathrm{y}$ axis is percentage of mortality.

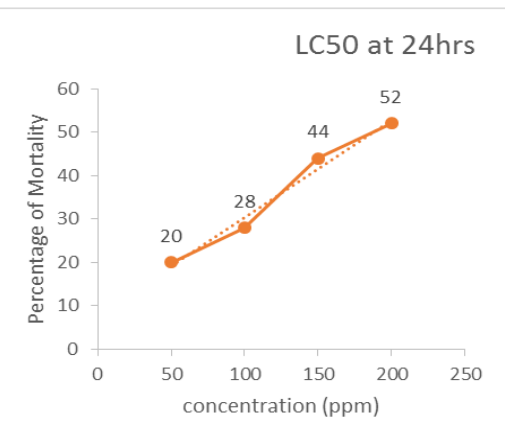

Figure 5. LC50 for 24 hours

$$
y=0.224 x+8
$$

Since, $y$ is $\mathbf{5 0}$,

$$
\begin{gathered}
50=0.224 \mathrm{x}+8 \\
\mathrm{x}=(50-8) / 0.224 \\
\mathrm{x}=187.5
\end{gathered}
$$

LC50 for 24 hours is $\mathbf{1 8 7 . 5} \mathbf{~ p p m}$.

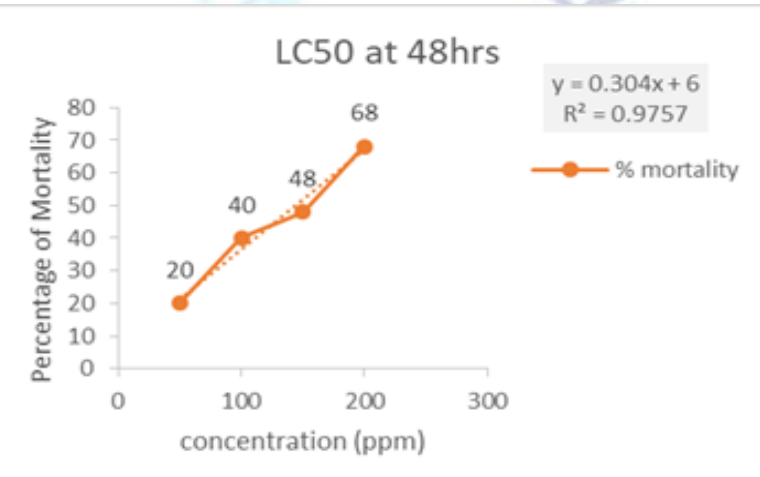

Figure 6. LC50 for 48 hours

$$
y=0.304 x+6
$$

Since, $\mathrm{y}$ is $\mathbf{5 0}$,

$$
\begin{gathered}
50=0.304 x+6 \\
x=(50-6) / 0.304 \\
x=144.7
\end{gathered}
$$

LC50 for 48 hours is $\mathbf{1 4 4 . 7} \mathbf{~ p p m}$.

\section{Mosquito Coil Making}
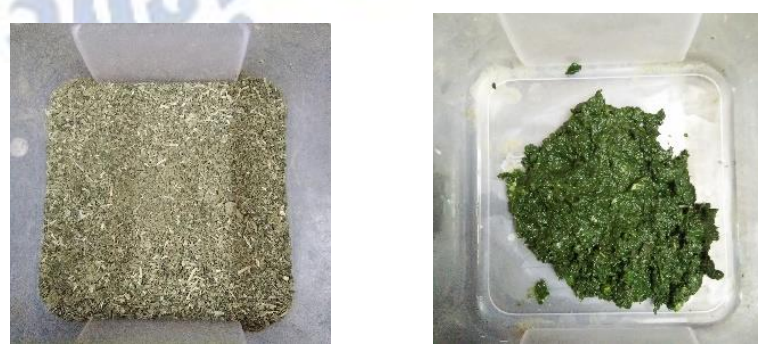

Figure 7.

Pulverized leaves

(Grinded)

Figure 8. Fresh leaves 


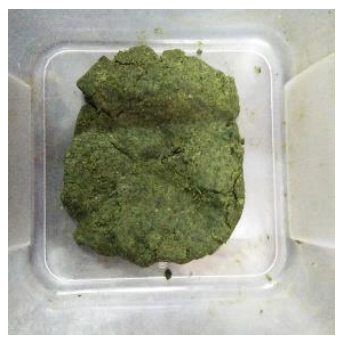

Figure 9. Coil mix

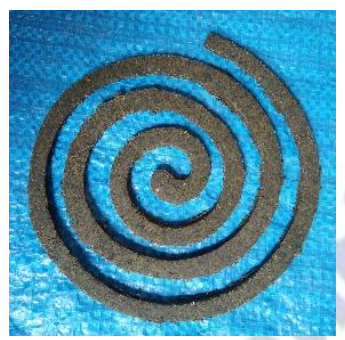

Figure 11. Drying coil

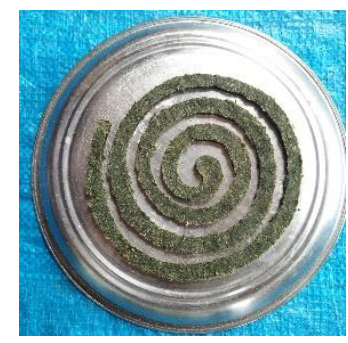

Figure 10. Molding

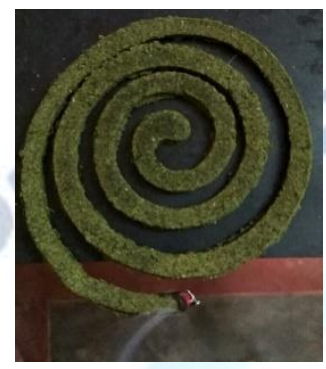

Figure 12. Coil Testing

\begin{tabular}{|l|c|c|}
\hline \multicolumn{1}{|c|}{ TEST } & HOUSE 1 & HOUSE 2 \\
\hline Repllent Activity & Good & Good \\
\hline Irritability & No & No \\
\hline Odor & No & No \\
\hline Smoke Visibility & Moderate & Moderate \\
\hline Burning time & $1 \mathrm{~h}$ & $1 \mathrm{~h}$ \\
\hline Diameter & $13 \mathrm{~cm}$ & $13 \mathrm{~cm}$ \\
\hline Flexibility & No & No \\
\hline Color & green & green \\
\hline
\end{tabular}

Table 2. Mosquito coil efficiency test

\section{CONCLUSION}

This study strongly shows Tridax procumbeans leave has insecticidal property and larvicidal property against mosquitos. It shows that $187.5 \mathrm{ppm}$ and $144.7 \mathrm{ppm}$ as LC50 for $24 \mathrm{hrs}$ and 48 hrsrecpectively. . Mosquito repellent product from Tridax procumbeansis effective and cost effective one. As it is a type of weed plant using as an insecticidal for crops is not suitable, but it is best for home pest control. The recent studies also showed Tridax procumbeans is also effective in controlling house flies.

\section{ACKNOWLEDGEMENT}

The author express their gratitude towards the host Institution Dr.N.G.P. Arts and Science college and DST-FIST Scheme, DBT-Star Scheme, Management, Principal, Deans, Head of the department, guide and other all other staffs of Department of biotechnology for rendering all the facilities and support. Communication no: DrNGPASC 2020-21 BS005.

\section{REFERENCES}

[1] Abubakar, A., Ogbadoyi, E. O., Okogun, J. I., Gbodi, T. I., \&Tifin, U. F. (2012). Acute and sub chronic toxicity of Tridax procumbens in experimental animals. Journal of Environmental Science Toxicology and Food Technology, 1, 19-27.

[2] Ahirwar, V., Singh, K., Rani, S., Srivastava, A., \&Gul, T. (2010). Effect of Tridax procumbens on protein contents of various organs in female albino rats. Int $\mathrm{J}$ PharmaceutSci Res, 1(9), 78-81.

[3] Appiah-Opong, R., Nyarko, A. K., Dodoo, D., Gyang, F. N., Koram, K. A., \&Ayisi, N. K. (2011). Antiplasmodial activity of extracts of Tridax procumbens and Phyllanthusamarus in in vitro Plasmodium falciparum culture systems. Ghana medical journal, 45(4).

[4] Bhagwat, D. A., Killedar, S. G., \&Adnaik, R. S. (2008). Anti-diabetic activity of leaf extract of Tridax procumbens. International Journal of Green Pharmacy (IJGP), 2(2).

[5] Christudas, S., Kulathivel, T. M., \&Agastian, P. (2012). Phytochemical and antibacterial studies of leaves of Tridax procumbens L. Asian pacific journal of tropical Biomedicine, 2(1), S159-S161.

[6] Elumalai, D., Kaleena, P. K., Fathima, M., \& Kumar, N. (2013). Phytochemical screening and larvicidal activity of Tridax procumbens (L) against Anopheles stephensi (Liston), Aedesaegypti (L) and Culexquinquefasciatus (say). International Journal of Bioscience Research, 2.

[7] Hemalatha, R. (2008). Anti-hepatotoxic and anti-oxidant defense potential of Tridax procumbens. International journal of green pharmacy, 2(3), 164.

[8] Ikewuchi, J. C. (2012). Alteration of plasma biochemical, haematological and ocular oxidative indices of alloxan induced diabetic rats by aqueous extract of Tridax procumbens Linn (Asteraceae). EXCLI journal, 11, 291.

[9] Ikewuchi, C. C., Ikewuchi, J. C., \&Ifeanacho, M. O. (2015). Phytochemical composition of Tridax procumbens Linn leaves: Potential as a functional food. Food and Nutrition Sciences, 6(11), 992.

[10] Jude, C. I., Catherine, C. I., \&Ngozi, M. I. (2009). Chemical profile of Tridax procumbens Linn. Pakistan Journal of Nutrition, 8(5), 548-550.

[11] Kamble, S. I., \&Dahake, P. R. (2015). Preliminary phytochemical investigation and study on antimicrobial activity of Tridax Procumbens Linn. International Refereed Multidisciplinary Journal of Contemporary Research, 2(3), 388-394.

[12] Kulkarni, P., Kinagi, N., Deshpande, P. R., \&Chavadi, V. DEVELOPMENT OF HERBAL MOSQUITO REPELLENT INCENSE STICK-AN OBSERVATIONAL STUDY. 
[13] Kumar, S., Prasad, A., Iyer, S. V., \& Vaidya, S. (2012). Pharmacognostical, phytochemical and pharmacological review on Tridax procumbens Linn. International Journal of Pharmaceutical \& Biological Archives, 3(4), 747-751.

[14] Manjamalai, A., Alexander, T., \& Grace, V. B. (2012). Bioactive evaluation of the essential oil of Plectranthus amboinicus by GC-MS analysis and its role as a drug for microbial infections and inflammation. Int $\mathrm{J}$ Pharm PharmSci, 4(3), 205-211.

[15] Manjamalai, A., \& Grace, V. M. (2012). Antioxidant activity of essential oils from Wedeliachinensis (Osbeck) in vitro and in vivo lung cancer bearing C57BL/6 mice. Asian Pacific Journal of Cancer Prevention, 13(7), 3065-3071.

[16] Mathew, N., Anitha, M. G., Bala, T. S. L., Sivakumar, S. M., Narmadha, R., \&Kalyanasundaram, M. (2009). Larvicidal activity of Saracaindica, Nyctanthes arbor-tristis, and Clitoriaternatea extracts against three mosquito vector species. Parasitology research, 104(5), 1017-1025.

[17] Martín-Quintal, Z., Moo-Puc, R., Gonzalez-Salazar, F., Chan-Bacab, M. J., Torres-Tapia, L. W., \&Peraza-Sánchez, S. R. (2009). In vitro activity of Tridax procumbens against promastigotes of Leishmaniamexicana. Journal of Ethnopharmacology, 122(3), 463-467.

[18] Meshram, R. L., \&Patil, M. B. (2011). Demonstration of anti-inflammatory activity of alcoholic and hydro-alcoholic extracts of Tridax procumbens using the rat paw edema assay. Biosci. Biotech. Res. Comm, 4(1), 47-51.

[19] Monika, T., Sasikala, P., \& Reddy, D. V. B. (2013). A Study on In vitro Phytochemical Screening and Antibacterial Activity of Aqueous and Methanolic Leaf Extracts of Tridax procumbens against Bovine Mastitis Isolated Staphylococcus aureus. International journal of advanced scientific and technical research, 4(3), 263-272.

[20] Nivedita, Ghayal, PadhyeAnand, and DhumalKondiram. "Larvicidal activity of invasive weeds Cassia uniflora and Synedrellanodiflora." International Journal of Pharma and Bio Sciences 1, no. 3 (2010).

[21] Pande, P. S., Mane, V. D., Mishra, M. N., \&Rothe, S. P. (2013). Antioxidant Activity of Phytoconstituents Isolated from Leaves of Tridax procumbens. Int. J. of PharmTech Res, 5, 1640-1644.

[22] Prabhu, V. V., Nalini, G., Chidambaranathan, N., \&Kisan, S. S. (2011). Evaluation of anti-inflammatory and analgesic activity of Tridax procumbens Linn. against formalin, acetic acid and CFA induced pain models. Int $\mathrm{J}$ Pharm PharmSci, 3(2), 126-130.

[23] Prajapati, K. (2008). Pharmacognostical and Preliminary Phytochemical Studies of Leaves of Tridax procumbens L. Ethnobotanical Leaflets, 2008(1), 172.

[24] Rajkumar, S., \&Jebanesan, A. J. T. B. (2007). Repellent activity of selected plant essential oils against the malarial fever mosquito Anopheles stephensi. Trop Biomed, 24(2), 71-75.

[25] Sawant, R. S., \&Godghate, A. G. (2013). Preliminary phytochemical analysis of leaves of Tridax procumbens Linn. International Journal of Science, Environment and Technology, 2(3), 388-394.

[26] Saxena, M., Mir, A. H., Sharma, M., Malla, M. Y., Qureshi, S., Mir, M. I., \&Chaturvedi, Y. (2013). Phytochemical screening and in-vitro antioxidant activity isolated bioactive compounds from Tridax procumbens Linn. Pak $\mathrm{J}$ BiolSci, 16(24), 1971-7.

[27] Sonawane, A., Srivastava, R. S., Sanghavi, N., Malode, Y., \&Chavan, B. (2014). Anti-diabetic activity of Tridax procumbens. Journal of Scientific and Innovative Research, 3(2), 221-226.
[28] Talekar, Y. P., Das, B., Paul, T., Talekar, D., Apte, K. G., \&Parab, P. B. (2012). Evaluation of wound healing potential of aqueous and ethanolic extracts of tridax procumbenslinn. In wistar rats. Asian Journal of Pharmaceutical and Clinical Research, 5(4), 141-145.

[29] Tejaswini, K., Vishwanath Pradeep, B., Rudrama Devi, K., Shylaja, S., \&Jyothsna, K. (2011). Phytochemical screening and antimicrobial activities of plant extract of Tridax procumbens. The Bioscan, 6(2), 321-323.

[30] Vishnu Priya, P., Radhika, K., Siva Kumar, R., Sri Ramchandra, M., Prameela Devi, Y., \&Srinivas Rao, A. (2011). Evaluation of anti-cancer activity of Tridax procumbens flower extracts on PC 3 Cell lines. Pharmanest, 2(1), 28-30.
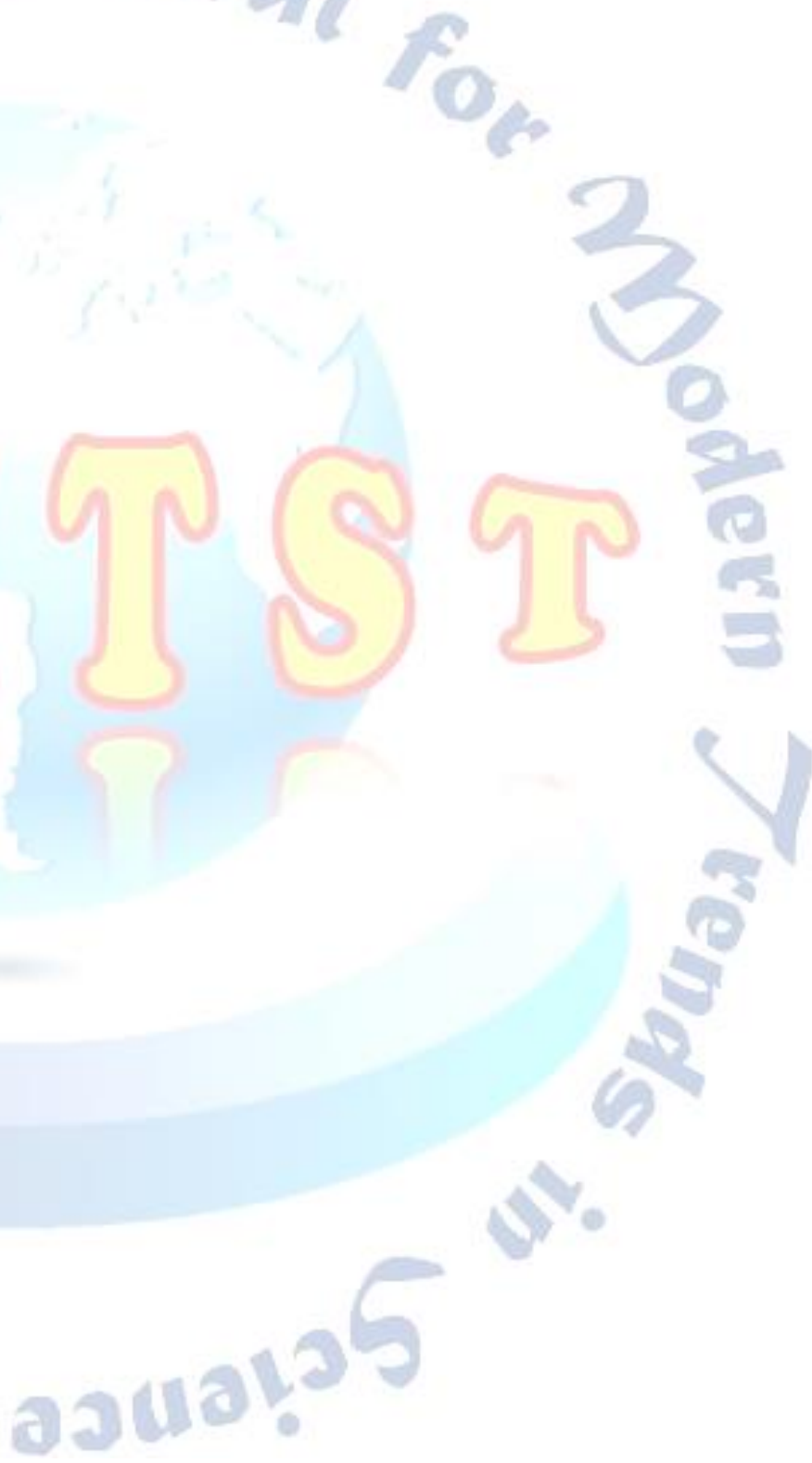